\title{
Phenolic acid content of sorghum and maize cultivars varying in hardness
}

Constance Chiremba $^{\mathrm{a}, \mathrm{b}}$, John R.N. Taylor ${ }^{\mathrm{b}}$, Lloyd W. Rooney ${ }^{\mathrm{c}}$, Trust Beta ${ }^{\mathrm{a}, \mathrm{d}, *}$

${ }^{a}$ Department of Food Science, University of Manitoba, Winnipeg, MB, Canada R3T 2N2

${ }^{\mathrm{b}}$ Department of Food Science, University of Pretoria, Private Bag X20, Hatfield 0028, South Africa

${ }^{c}$ Cereal Quality Laboratory, Department of Soil and Crop Sciences, Texas A\&M University, College Station, Texas 77843-2474, USA

${ }^{\mathrm{d}}$ Richardson Centre for Functional Foods and Nutraceuticals, Smartpark, University of Manitoba, Winnipeg, Manitoba, Canada R3T 2N2

* Corresponding author. Address: Department of Food Science, University of Manitoba, Winnipeg, MB, Canada R3T 2N2. Tel.: +1 204474 8214; fax: +1 2044747630.

E-mail address: Trust_Beta@umanitoba.ca

Submitted to Food Chemistry 


\begin{abstract}
The role of phenolic acids on sorghum and maize hardness was evaluated among eight cultivars of each of the cereals representing hard and soft classes. Bran and flour fractions were evaluated for monomeric and diferulic phenolic acids using high performance liquid chromatographic and mass spectrometric (LC-MS/MS) techniques. Bran samples of harder grains had more phenolic acids than those of soft types. Intra-class testing showed slight differences in cultivars within the hard and soft classes. The content of phenolic acids was a useful indicator of hardness distinguishing between hard and soft maize and sorghum cultivars. Correlation coefficients between monomeric acids of maize bran, mostly ferulic acid, and grain hardness were higher than those of sorghum. Maize bran ferulic acid content was strongly correlated with Tangential Abrasive Dehulling Device (TADD) hardness ( $\mathrm{r}=$ $0.776, \mathrm{p}<0.001)$. This study is the first to show that there is a relationship between bran phenolic acid content and sorghum and maize hardness.
\end{abstract}

Keywords: phenolic acids, ferulic acid, hardness, maize, sorghum 


\section{Introduction}

Dry milling quality of sorghum and maize primarily depends on hardness involving abrasive decortication and roller milling respectively, to obtain grits or meal. Hard grain types are desirable to obtain high extraction rates. Several physical tests have been used to estimate sorghum and maize grain hardness including density (AACC International 2010; Paulsen, Watson \& Singh 2003), endosperm texture (Rooney \& Miller 1982; Taylor 2003), breakage susceptibility, stress cracking and decortication (Reichert, Tyler, York, Schwab, Tatarynovich \& Mwasaru, 1996). Alternatively digital image analysis can be used to measure grain translucency (Erasmus \& Taylor 2004; Louis-Alexandre, Mestres \& Faure, 1991) and near infrared transmittance and reflectance spectroscopy to estimate grain hardness (Robutti 1995; Wehling, Jackson \& Hamaker, 1995). These physical tests can only effectively differentiate between samples varying greatly in hardness (Duarte, Mason, Jackson \& Kiehl, 2005, Johnson et al 2010). However, in the real situation, the range of hardness encountered is small as commercial cultivars have been selected for specific quality attributes and tend to be closely related. Hence, screening for hardness among closely related cultivars presents a problem to the milling industry.

The biochemical basis for grain hardness is not well understood particularly in maize although the quantity and distribution of $\gamma$-kafirins is thought to play a major role in sorghum hardness (Mazhar \& Chandrashekar, 1995). Therefore, there is a need to determine measurements that can be used in such a situation. Phenolic acids are thought to play a role in grain hardness (García-Lara, Bergvinson, Burt, Ramputh, Díaz-Pontones \& Arnason, 2004, Del Pozo-Insfran, Brenes, Saldivar \& Talcott 2006). The high concentration and cross linking of phenolic acids to cell walls of the pericarp and aleurone layers is important. Thus phenolic acids may affect structural properties that affect grain hardness.

The purpose of the study was to identify and quantify bound phenolic acids of sorghum and maize cultivars varying slightly in hardness to determine the relationship between phenolic acid types and content and grain hardness. A relationship between phenolic acids and hardness may mean that phenolic acids could be used as markers for sorghum and maize grain hardness.

\section{Materials and methods}

\subsection{Samples}


A study was conducted on eight sorghum and eight maize cultivars grown in South Africa representing commercial hybrids from the National Cultivar Trials harvested during the 2008/2009 growing season. Maize cultivars were white dent types grown in Potchefstroom. Sorghum cultivars were red, non-tannin grown in Platrand. The cultivars were all grown in one location so as to eliminate environmental effects on phenolic content. All cultivars were grown in dryland conditions, harvested at less than $14 \%$ moisture and dried slowly. Cultivars were classified as hard and soft according to the percentage of kernel removed by the Tangential Abrasive Dehulling Device (TADD). All samples were thoroughly cleaned to remove broken and foreign material threshed and cleaned samples were stored at $4^{\circ} \mathrm{C}$ until analyses.

\subsection{Physical and hardness tests}

Test weight (TW) was determined as outlined in the United States Department of Agriculture (USDA) Grain Inspection, Packers and Stockyards Administration (GIPSA) Handbook according to GIPSA, (2007) section 1.11. A $100 \mathrm{~g}$ sorghum sample was manually sieved through stacked $4.00 \mathrm{~mm}, 3.35 \mathrm{~mm}, 3.15 \mathrm{~mm}$ and $2.36 \mathrm{~mm}$ round hole sieves to determine kernel size. Maize kernels were sieved through an $8 \mathrm{~mm}$ round hole sieve. Grain hardness was determined with a Tangential Abrasive Dehulling Device (TADD, Model 4E115, Venables Machine Works, Saskatoon, SK, Canada) as percentage weight abraded from a $50 \mathrm{~g}$ sorghum or maize sample, decorticated for $5 \mathrm{~min}$. For phenolic assays, bran and flour portions were separated by decorticating grain to $80 \%$ extraction rate. Separation was achieved by optimizing decortication time for each cultivar to abrade $20 \%$ of the kernel. One thousand kernels were weighed on a calibrated scale to obtain a Thousand Kernel Weight (TKW). Maize milling index was measured using Near Infrared Transmittance (NIT) spectrophotometry, (Infratec 1241, Grain Analyzer, Foss Tecator, Eden Prairie, MN) that was

calibrated against a three break roller milling process. Breakage susceptibility was determined by running a $100 \mathrm{~g}$ sample of whole maize kernels in a Stein Breakage tester for 4 min and weighing the mass of broken kernels.

\subsection{Sample preparation}

Maize and sorghum grains were decorticated with a TADD to $80 \%$ extraction rates to obtain bran and flour fractions. Bran was ground with a cyclone mill UDY Cyclotec Sample Mill (UDY Corporation, Fort Collins, Colorado, USA) passed through a $0.5 \mathrm{~mm}$ opening 
screen. The ground fractions were wrapped tightly in plastic samples bags and stored at $20^{\circ} \mathrm{C}$ before analyses of total phenolic content and phenolic acids.

\subsection{Chemicals}

Folin-Ciocalteu reagent and phenolic acid standards were purchased from SigmaAldrich Chemical Co. (St. Louis, MO, USA). HPLC grade hexane, ethyl acetate and methanol used for extraction of phenolics and MS grade methanol and acetic acid used in LC-MS/MS were also purchased from Sigma-Aldrich Chemical Co. (St. Louis, MO, USA).

\subsection{Total phenolic content (TPC)}

A modified Folin-Ciocalteu method was used (Waterman \& Mole, 1994). Briefly, phenolic extracts were prepared in $15 \mathrm{ml}$ acidified methanol (1\% conc. $\mathrm{HCl}$ in methanol, v/v) from $1 \mathrm{~g}$ flour or bran samples. Centrifuged extracts were mixed with Folin Ciocalteu phenol reagent and then with sodium carbonate $(20 \%$, w/v) solution within $8 \mathrm{~min}$ from the addition of the phenolic reagent. The contents were left to stand for $2 \mathrm{~h}$, after which absorbance was read at $734 \mathrm{~nm}$ using a Lambda EZ150 spectrophotometer (Perkin Elmer, USA). Catechin was used as a standard.

\subsection{Extraction of bound phenolic acids}

Soluble phenolics were extracted according to Qiu, Liu and Beta (2010), with modifications. Ground flour and bran samples $(1 \mathrm{~g})$ were extracted twice with $80 \%$ methanol (v/v) $(15 \mathrm{ml})$ for $1 \mathrm{~h}$ by mechanical shaking. The methanolic mixture was centrifuged at 2683 $\mathrm{g}$ for 5 min with a multispeed centrifuge The residue was retained for alkaline hydrolysis and washed with distilled water to remove organic solvent and filtered through Whatman No. 1 filter paper. Then $200 \mathrm{mg}$ portion of the residue was hydrolyzed at room temperature using $\mathrm{NaOH}$ under nitrogen to release insoluble ester linked phenolics. To optimize the extraction method, different extraction times and alkaline concentrations varying from 2 to $24 \mathrm{~h}$ and 2 to $4 \mathrm{M} \mathrm{NaOH}$ respectively, were tried. Hydrolysis for $2 \mathrm{~h}$ using $2 \mathrm{M} \mathrm{NaOH}$ was found sufficient for the release of phenolic acids. The hydrolysate was adjusted to a $\mathrm{pH}$ of 1.5 to 2.0 using $6 \mathrm{M}$ $\mathrm{HCl}$ and extracted three times with $15 \mathrm{ml}$ hexane to remove lipids. The organic phase was removed with a separator and the aqueous phenolic phase extracted three times with ethyl acetate to obtain the alkali released phenolics. The organic phase was further dehydrated with $1 \mathrm{~g} \mathrm{Na}_{2} \mathrm{SO}_{4}$. The combined ethyl acetate extracts were dried and concentrated under vacuum using a rotary evaporator. The dried phenolic extracts were redissolved in $2 \mathrm{ml}$ of $50 \%$ 
methanol and filtered through $0.45 \mu \mathrm{m}$ and $0.22 \mu \mathrm{m}$ PTFE filters before HPLC and MS/MS analyses, respectively.

\subsection{HPLC-MS/MS analysis}

HPLC analysis of phenolic acids was performed on a Waters 2695 HPLC (Waters, Milford, MA) equipped with a Waters 996 photodiode array (PDA) and a reverse phase ShimPack HRC-ODS , C18 (250 x $4.6 \mathrm{~mm}$ ) analytical column (Shimadzu, Kyoto, Japan) and an auto sampler (717 Plus, Waters) to inject $20 \mu \mathrm{L}$ of sample. The gradient mobile phase solvent $\mathrm{A}$ was $0.1 \%$ acetic acid in high purity water and solvent $\mathrm{B}$ was $0.1 \%$ acetic acid in methanol. Phenolic acid separation was achieved using a 70 min linear solvent gradient at a flow rate of $0.7 \mathrm{ml} / \mathrm{min}$, as follows: $0 \min 4 \% \mathrm{~B}, 18 \min 18 \% \mathrm{~B}, 35 \min 30 \% \mathrm{~B}, 58 \min 42 \%$ $\mathrm{B}, 70 \mathrm{~min} 60 \% \mathrm{~B}$, and $10 \mathrm{~min}$ to rinse and equilibrate the column. Phenolic acid quantification was based on the standard curves of the corresponding phenolic acids at a wavelength of $320 \mathrm{~nm}$ and peak area was used for calculations. Identification of phenolic acids was performed by comparison to the retention time and MS/MS spectra with external standards. MS/MS was conducted using a quadrupole time-of-flight mass spectrometer (QTOF MS) (Micromass, Waters Corp., Milford, MA). Full mass spectra were acquired in the negative mode using cone and capillary voltages of $30 \mathrm{~V}$ and $1.6 \mathrm{kV}$, respectively. Desolvation and cone gases $(\mathrm{He})$ were set to flow at $900 \mathrm{~L} / \mathrm{h}$ and $35 \mathrm{~L} / \mathrm{h}$, respectively while the desolvation temperature and the source temperatures were $350{ }^{\circ} \mathrm{C}$ and $150{ }^{\circ} \mathrm{C}$, respectively. MS/MS spectra were acquired using collision energy of $25 \mathrm{~V}$ in the range $\mathrm{m} / \mathrm{z}$ $100-1500$.

\subsection{Statistical analyses}

All extracts were analyzed three times. Means were compared by Fisher's Least Significant Differences (LSD) and significant differences were reported at $\mathrm{p}<0.05$. Pearson's correlation was performed to determine the relationship between phenolic acids and grain hardness.

\section{Results and discussion}

\subsection{Physical and hardness characteristics of sorghum and maize cultivars}

The physical and hardness properties of sorghum and maize cultivars are shown in Tables 1a and 1b. In general, analysis of variance could not verify significant differences 
among the cultivars in terms of physical properties; however, cultivars were simply ranked into hard and soft using TADD as a common measure of hardness for both sorghum and maize. The hard and soft sorghum cultivars had on average 33.3 and $42.6 \%$ kernel removed by TADD abrasion versus 24.1 and $30.3 \%$ for hard and soft maize types, respectively. The average TKW was slightly higher but not significantly different for hard compared to soft cultivars of both grain types. However, there were significant differences in kernel sizes between 3.35 and $4.00 \mathrm{~mm}$ for hard and soft sorghums (Table 1a). As expected, the breakage susceptibility (SB) was generally high for all soft maize cultivars except for PAN 4P-313B while NIT milling index was generally low for all soft types except for cultivar AFG 4473. Both the breakage susceptibility and milling index are somewhat related to grain hardness.

\subsection{Total phenolic content of sorghum and maize bran and flour methanolic extracts}

Bran TPC of hard sorghum and maize cultivars differed significantly $(\mathrm{p}<0.05)$ from that of soft cultivars (Table 2). The significant differences $(\mathrm{p}<0.05)$ between hard and soft cultivars could mean that bran TPC may be used as an indicator of sorghum and maize hardness. However, a comparison of TPC among cultivars of similar hardness or softness, TPC may not be useful to distinguish individual cultivars in the same hardness group. TPC of the flours, contributed mainly by the endosperm, seemed consistent in all cultivars and was not affected by grain hardness. Since phenolic compounds are concentrated in the bran (Awika, McDonough \& Rooney, 2005; Beta, Rooney, Marovatsanga \& Taylor, 2000) it was expected that TPC in the flour would not vary to a large extent. In contrast, soft wheat bran and flour fractions had significantly $(\mathrm{p}<0.05)$ higher phenolic content than fractions of hard wheat (Liyana-Pathirana \& Shahidi, 2006). Since most of the phenolic compounds exist in bound form (> 85\%) in maize (Adom \& Liu, 2002) and other cereals, the samples were hydrolysed to release the major portion of the bound phenolic compounds and further identified and quantified with HPLC.

\subsection{Alkaline hydrolysis of bound phenolic acids}

Release of phenolic acids was optimized by using $2 \mathrm{M} \mathrm{NaOH}$ for $2 \mathrm{~h}$. NaOH concentrations greater than $2 \mathrm{M}$ and longer extraction periods resulted in poorly resolved peaks. With prolonged hydrolysis, a number of changes are thought to occur such as oxidation and dimerization of phenolic compounds (Bunzel et al., 2003). Torre, Aliakbarian, Rivas, Dominguez and Converti (2008) studied the kinetics of ferulic acid release after $2 \mathrm{~h}$ of extraction with $2 \mathrm{M} \mathrm{NaOH}$. Their findings were that a threshold existed for maximum ferulic 
acid solubilisation (1100 to $1200 \mathrm{mg} / \mathrm{L}$ ). Thereafter, ferulic acid concentration decreased, the decline of which was attributed to oxidative degradation. Adom and Liu (2002) used similar extraction conditions citing minimal phenolic acid loss.

\subsection{Phenolic acid composition of sorghum and maize cultivars}

Four simple phenolic acids were identified in the alkaline hydrolysates, namely caffeic acid (CA), p-coumaric acid (PCA), ferulic acid (FA) and sinapic acid (SA) against standards. All of the phenolic acids were identified in sorghum bran and only PCA and FA were found in the sorghum flour. In maize, PCA, FA and SA were found in the bran fraction and only PCA and FA were detectable in the flour.

\subsection{Bound phenolic acids of sorghum bran and flour fractions}

FA content was significantly different $(\mathrm{p}<0.05)$ among bran of hard and soft sorghum cultivars (Table 3a). FA was the most abundant phenolic acid in sorghum bran (1727 to $3532 \mu \mathrm{g} / \mathrm{g}$ ) as previously reported in several grains including maize, rice, wheat, buckwheat, millet, sorghum, rye and barley (Bily, et al., 2004; Dobberstein \& Bunzel, 2010; Gallardo, Jiménez \& García-Conesa, 2006; Li, Wei, White \& Beta, 2007; Ring, Waniska \& Rooney, 1988; Rao \& Muralikrishna, 2004). Within the hard cultivars, bran FA was similar except for PAN 8488 which had significantly lower $(\mathrm{p}<0.05)$ content than other cultivars. Bran from hard sorghum grains had two times more PCA than soft types (Table 3a). Similar to findings with FA, the trends in the quantities of PCA between hard and soft sorghums demonstrated that hardness could be related to phenolic acid content and type.

However, SA was slightly higher in the bran of soft cultivars than the hard ones. Only PCA and FA were found in flour, almost two and seventeen times, respectively, lower than in bran. The content of PCA and FA of hard sorghum flours was, respectively, three and two times more than soft types, an indication that the phenolic acid content can be used to distinguish between hard and soft cultivars even in low amounts such as those found in the flour compared to bran. PAN 8488 had bran total phenolic acid content (BTPC) that differed significantly $(\mathrm{p}<0.05)$ with other grains within the hard cultivars. Total phenolic acid content (FTPA) of soft sorghum flour was about 50\% that of hard type flours. The significant differences $(p<0.05)$ in phenolic acid content between hard and soft cultivars imply that phenolic acids have an effect on grain hardness.

\subsection{Bound phenolic acids of maize bran and flour fractions}


FA had the highest content among acids quantified in maize bran (Table 3b). Significant differences were observed among hard and soft maize grains. The mean FA of hard type maize bran $(3214 \mu \mathrm{g} / \mathrm{g})$ was significantly higher $(\mathrm{p}<0.05)$ than that of soft types $(2198 \mu \mathrm{g} / \mathrm{g})$. However, LS $8521 \mathrm{~B}$ bran had 18\% less FA than other hard cultivars. Within the soft types, bran of PAN 4P - 313 B had at least $28 \%$ more FA. FA content of $2480 \mathrm{mg} / \mathrm{kg}$ was reported in white maize of intermediate to hard flour texture (Del Pozo-Insfran et al., 2006). This FA content is similar to the levels found in bran samples from soft cultivars. Similar to FA, bran PCA of hard types was higher (two times) than that of soft types. Within hard and soft cultivars, AFG 4555 and PAN 6223 B had significantly $(\mathrm{p}<0.05)$ high and low PCA contents, respectively.

FA and PCA occurred in lower amounts in flour compared to the bran, due to low concentrations of phenolic compounds in the endosperm, which comprised most of the flour component. Only $6 \%$ and $4 \%$ of bran FA occurred in hard and soft grain flours, respectively. PCA was also lower in flours compared to bran, by a margin of 22 to $32 \%$. In terms of grain hardness, $6.6 \mathrm{mg} / \mathrm{kg}$ PCA was reported in hard to intermediate white maize (Del Pozo-Insfran et al., 2006) lower than values in this study likely due to cultivar differences and extraction methods.

\subsection{Identification and quantification of diferulic acids}

The identification of diferulic acids (DFAs) was confirmed by their mass spectra in comparison with literature. By performing a scan at $\mathrm{m} / \mathrm{z}$ 385, typical of diferulates, four DFAs were identified in the bran of both hard and soft sorghum and maize cultivars (Fig 1a and 1b). The DFAs were assigned 8-5' (A), 5-5' (B), 8-O-4' (C) and 8-5'benzofuran form, in agreement with mass spectra data and fragmentation patterns (Bily et al., 2004; Callipo, Cavaliere, Fuscoletti, Gubbiotti, Samperi \& Laganà 2010; Qiu, Liu \& Beta 2010). All the deprotonated diferulic acids $[\mathrm{M}-\mathrm{H}]^{-}$produced a fragment $\mathrm{m} / z, 341$ due to the loss $\mathrm{CO}_{2}(44 \mathrm{u})$ from the carboxylic acid group (Figures 1b). The fragmentation pattern is characteristic of phenolic acids with the resultant $[\mathrm{M}-\mathrm{H}-\mathrm{COO}]^{-}$anion (Parejo, Jauregui, Sànchez-Rabaneda, Viladomat, Bastida \& Codina, 2004; Hossain, Rai, Brunton, Martin-Diana \& Barry-Ryan, 2010). The DFAs 8-O-4' and 8-5'benzofuran form were the most abundant confirming previous reports, thus used for quantification (Andreasen, Christensen, Meyer \& Hansen, 2000; Waldron, Parr, Ng \& Ralph, 1996). 
Only DFAs of bran were quantified as the flours contained very low amounts since most of these oligomeric compounds occur in dietary fibre (Bunzel, Ralph, Marita, Hatfield \& Steinhart, 2001). Due to lack of standards, FA was used for their quantification. DFAs of sorghum and maize were higher in bran of hard cultivars than soft ones. The presence of DFAs in bran could enhance cross linking with arabinoxylan chains (Gallardo et al., 2006) hence affecting grain mechanical properties (Renger \& Steinhart, 2000). Arabinoxylans were shown to have a greater effect in modifying grain hardness in soft wheat than in hard wheat (Bettge \& Morris 2000). High levels of polymer similar to water soluble arabinoxylans characterized the peripheral endosperm of soft wheat cultivars (Barron, Parker, Mills, Rouau $\&$ Wilson 2005). Within the class of soft sorghum cultivars, PAN 8903 apparently had DFA content similar to that of hard sorghums. Within hard maize cultivars, IMP 52-11 and DKC 77-61 B could be distinguished from AFG and LS 8521 B as having less DFA content than the latter. In the case of soft types, cultivar AFG 4473 had DFA content comparable to that of IMP 52-11, a hard type.

\subsection{Relationship between phenolic acids of sorghum and maize with hardness parameters}

To confirm the relationships and possible role of sorghum and maize phenolic acids to hardness, Pearson's correlation coefficients were determined as shown in Tables $4 \mathrm{a}$ and $4 \mathrm{~b}$, respectively. FA, as the major phenolic acid quantified, was significantly negatively correlated with TADD $(r=-0.447, \mathrm{p}<0.05)$ of sorghum bran. Although the results indicated a significant correlation between TADD and FA, the relationship was not strong explaining $22 \%$ variation contributed by these factors. BTPA was also weakly negatively correlated with TADD $(r=-0.474, p<0.05)$. Correlations of BFA and BTPA with TW were slightly stronger than those for TADD $(\mathrm{r}=0.611, \mathrm{p}<0.05)$ and $(\mathrm{r}=0.597, \mathrm{p}<0.05)$, respectively. The significant correlation between BSA and sorghum kernel size $(>2.36<3.35 \mathrm{~mm}$ ) was unexpected hence further investigations are needed to confirm this linkage.

On the contrary, maize phenolic acids showed stronger correlations with grain physical properties than sorghum. The phenolic acids were mostly correlated with TADD hardness (Table $4 \mathrm{~b}$ ). TADD of maize bran was significantly correlated with BFA, BTPC, BSA, FPCA, FFA, BTPA, FTPA. The notable correlations at $p<0.001$ were between TADD with BTPC $(r=-0.717)$, BFA $(r=-776)$ and FTPA $(r=-0.730)$. The correlation between FTPA and grain hardness is noteworthy given the low phenolic acid content in the flour. Since bran is produced as offal during maize milling, the implication is that the retained flour could be evaluated for total phenolic acid content as an indicator of grain hardness. TW was correlated 
with FTPC $(r=0.503, \mathrm{p}<0.05)$ and BPCA $(\mathrm{r}=0.579, \mathrm{p}<0.05)$. Breakage susceptibility was negatively correlated with BTPC and BFA. The results clearly show that FA influences maize mechanical properties as the negative correlation implies that cultivars with low FA would break easily.

There have been suggestions that phenolic acids, in particular FA, could be related to grain hardness. Del Pozo-Insfran et al., (2006) compared FA of white and two blue maize genotypes varying in flour texture. The relatively harder white maize genotype had higher FA content $(2480 \mathrm{mg} / \mathrm{kg})$ than blue maize genotypes which contained $202 \mathrm{mg} / \mathrm{kg}$ and $927 \mathrm{mg} / \mathrm{kg}$. This present investigation confirms the role phenolic content and phenolic acid type, mainly FA and other hydroxycinnamic acids in maize hardness. At the biochemical level, this finding is needed to understand the basis of maize hardness which remains unresolved to date. Moreover, it shows that phenolic acid content and type could be used to distinguish between soft and hard maize cultivars with small variations in hardness as the case with the current cultivars. Despite differences in DFA content between hard and soft cultivars, the compounds did not significantly influence sorghum and maize hardness as previously reported by García-Lara et al., (2004). García-Lara et al., (2004) reported that diferulic acids 5, 5'-DiFA 8-O-4'-DiFA 8, 5'-DiFA and total DiFAs extracted from maize were significantly correlated $(\mathrm{p}<0.001)$ with whole grain hardness.

The mechanism by which phenolic acids may influence grain hardness may be related to chemical bonding through cross linking of the compounds within the plant cell walls. Most studies have shown the FA and its oligomers are the most prevalent in forming linkages with cell walls. FA simultaneously forms ester-ether linkages between the non-starch polysaccharide arabinoxylan and lignin (Lam, Iiyama \& Stone, 1992a). FA ester linkages are formed during early maturation to primary cell walls of grasses glucuronoarabinoxylans (Ishii 1997) and later react with lignin quinonemethide intermediates to form benzyl ether linkages in lignified cells walls at maturity (Lam Iiyama \& Stone, 1992b). The high quantities of FA in maize and sorghum could be related to its role in cross linkages with arabinoxylans and lignified cell walls. In addition, diferulic acids are mostly bound to lignin, by ether linkages further reinforcing the cell walls. However, in this study DFAs were not correlated with grain hardness. The release of DFAs could have been limited by the extraction at room temperature. Ether linkages are heat labile and are broken at the temperature used for refluxing while ester linkages are released at room temperature (Lam et al. 1992 a). According to Lam et al. (1992b) esterified diferulic acids released at room temperature were 10-20 times less than high temperature treatment. It is likely that dehydrodiferulic acid 
bridges between polysaccharides and lignins remained during alkaline hydrolysis since high temperatures are needed to release the etherified form.

PCA was the second most important phenolic acid after FA in terms of content. It is also likely to play a role in cell wall cross linking. Small amounts of PCA are esterified to arabinoxylan cell walls and more extensively to lignin cell walls at maturity (Lam et al. 1992b; Ralph, Hatfield, Quideau, Helm, Grabber \& Jung, 1994; Sun, Sun, Wang, Zhu \& Wang 2002). In maize, NMR studies revealed that PCA is lignified to cell walls at the $\gamma$ position of the lignin side chain (Ralph, et al. 2004) while Bunzel, Ralph, Lu, Hatfield and Steinhart (2004) confirmed the presence of lignin in cereal grains. Coupled with the FA ester linkages to arabinoxylan and etherification to lignin, PCA, is likely to form strong linkages with cell walls. However, our results did show significant correlations of PCA with grain physical properties except with TW in maize $(r=0.579, \mathrm{p}<0.05)$.

\section{Conclusions}

Phenolic acids, as a major group of bioactive components in cereal grains are considered as an intrinsic biochemical factor with potential contribution to variation in sorghum and maize hardness. This study is the first to show a relationship between phenolic acid content and sorghum and maize grain hardness. Sorghum and maize bran of harder grains have higher phenolic acid content than those of soft types. Maize phenolic acids seem to have greater effect on grain hardness than those of sorghum.Phenolic acid content could be useful as an indicator of hardness to distinguish between hard and soft types of these two types of cereals. The study indicates the role of FA in sorghum and maize grain hardness and its position as the most predominant phenolic acid.

\section{Acknowledgements}

The generous support from the Natural Science and Engineering Research Council of Canada (NSERC) Discovery Grant Program, Canada Foundation for Innovation (CFI) -New Opportunities Fund (CFI-NOF) and CFI-Leaders Opportunity Funds (CFI-LOF) is greatly appreciated. This work also acknowledges the technical support received from Yang Qiu of the Department of Food Science, University of Manitoba. The authors are grateful to the Agricultural Research Council for providing sorghum and maize grain samples for research. 


\section{References}

AACC International. (2010). Approved Methods of Analysis, 11th Ed. Method 55-10.01. AACC International: St. Paul, MN.

Adom, K. K., \& Liu, R. H. Antioxidant activity of grains. (2002). Journal of Agricultural and Food Chemistry, 50, 6182-6187.

Andreasen, M. F., Christensen, L. P., Meyer, A. S., \& Hansen, Å. (2000). Ferulic acid dehydrodimers in rye (Secale cereale L.). Journal of Cereal Science, 31, 303-307.

Awika, J. M., McDonough C. M., \& Rooney L. W. (2005). Decorticating sorghum to concentrate healthy phytochemicals, Journal of Agricultural and Food Chemistry 53, $6230-6234$.

Barron, C., Parker, M. L., Mills, E. N. C., Rouau, X., \& Wilson, R. H. (2005). FTIR imaging of wheat endosperm cell walls in situ reveals compositional and architectural heterogeneity related to grain hardness. Planta, 220, 667-677.

Beta, T., Rooney, L. W., Marovatsanga, L. T., \& Taylor, J. R. N. (2000). Effect of chemical treatments on polyphenols and malt quality in sorghum. Journal of Cereal Science, 31, 295-302.

Bettge, A. D., \& Morris, C. F., (2000). Relationships among grain hardness pentosan fractions and end-use quality of wheat. Cereal Chemistry, 77, 241-247.

Bily, A. C., Burt, A. J., Ramputh, A. L., Livesey, J., Regnault-Roger, C., Philogene, B. R., \& Arnason, J. T. (2004). HPLC-PAD-APCI/MS assay of phenylpropanoids in cereals. Phytochemical Analysis, 15, 9-15.

Bunzel, M. Ralph, J. Lu, F. Hatfield R. D. \& Steinhart, H. (2004). Lignins and ferulateconiferyl alcohol cross-coupling products in cereal grains. Journal of Agricultural and Food Chemistry, 52, 6496-6502.

Bunzel, M., Ralph, J., Kim, H., Lu, F., Ralph, S. A., Marita, J. M. Hatfield, R. D., \& Steinhart. H. (2003). Sinapate dehydrodimers and sinapate-ferulate heterodimers in cereal dietary fibre. Journal of Agricultural and Food Chemistry, 51, 1427-1434.

Bunzel, M., Ralph, J., Marita, J., Hatfield, R. D., \& Steinhart, H. (2001). Diferulates as structural components in soluble and insoluble cereal dietary fibre. Journal of Agricultural and Food Chemistry, 81, 653-660.

Callipo, L., Cavaliere, C., Fuscoletti, V., Gubbiotti, R., Samperi, R., \& Laganà, A. (2010). Phenilpropanoate identification in young wheat plants by liquid 
chromatography/tandem mass spectrometry: monomeric and dimeric compounds. Journal of Mass Spectrometry, 45, 1026-1040.

Dobberstein, D., \& Bunzel, M. (2010). Separation and detection of cell wall-bound ferulic acid dehydrodimers and dehydrotrimers in cereals and other plant materials by reversed phase high-performance liquid chromatography with ultraviolet detection. Journal of Agricultural and Food Chemistry, 58, 8927-8935.

Duarte, A. P., Mason, S. C., Jackson, D. S., \& Kiehl, D. C. (1995). Grain quality of Brazilian maize genotypes as influenced by nitrogen level. Crop Science, 45, 1958-1964.

Erasmus, C. \& Taylor, J. R. N. (2004). Optimising the determination of maize endosperm vitreousness by a rapid non-destructive image analysis technique. Journal of the Science of Food and Agriculture, 84, 920-930.

Gallardo, L., Jiménez, M. T., \& Garcia-Conesa. (2006). Hydroxycinnamic acid composition and in vitro antioxidant activity of selected grain fractions. Food Chemistry, 99, 455463.

García-Lara, S., Bergvinson, D., Burt, A. J., Ramputh, A. I., Díaz-Pontones, D. M., \& Arnason, J. T. (2004). The role of pericarp cell wall components in maize weevil resistance. Crop Science, 44, 1546-1552.

GIPSA (United States Department of Agriculture Grain Inspection, Packers and Stockyards Administration). (2007). Grain Inspection Handbook II. Chapters:4 Corn, 9 Sorghum.http://archive.gipsa.usda.gov/reference-library/handbooks/graininsp/grbook2/corn.pdf. (accessed 2 November 2009).

Hossain, M. B., Rai, D. K., Brunton, N. P., Martin-Diana, A. B., \& Barry-Ryan, C. J. (2010). Characterization of phenolic composition in Lamiaceae spices by LC-ESI-MS/MS. Journal of Agricultural and Food Chemistry, 58, 10576-81.

Ishii, T., 1991. Isolation and characterization of a diferuloyl arabinoxylan hexasaccharide from bamboo shoot cell-walls. Carbohydrate Research, 219, 15-22.

Johnson, W. B., Ratnayake,W. S., Jackson, D. S., Lee , K-M., Herrman, T. J., Bean, S. R., \& Jason, S. C. (2010). Factors affecting the alkaline cooking performance of selected corn and sorghum hybrids. Cereal Chemistry, 87, 524-531.

Lam, TB-T., Iiyama, K., \& Stone, B. A. (1992a). Cinnamic acid bridges between cell wall polymers in wheat and phalaris intemodes. Phytochemistry, 31, 1179-1183.

Lam, TB-T., Iiyama, K., \& Stone, B. A. (1992b). Changes in phenolic acids from intemode walls of wheat and phalaris during maturation. Phytochemistry, 31, 2655-2658. 
Li, W., Wei, C. V., White, P. J., \& Beta, T. (2007). High-amylose corn exhibits better antioxidant activity than typical and waxy genotypes. Journal of Agricultural and Food Chemistry, 55, 291-298.

Liyana-Pathirana, C. M., \& Shahidi, F. (2006). Importance of insoluble-bound phenolics to antioxidant properties of wheat. Journal of Agricultural and Food Chemistry, 54, $1256-1264$.

Louis-Alexandre, A., Mestres, C., \& Faure, J. (1991). Measurement of endosperm vitreousness of corn. A quantitative method and its application to African cultivars. Cereal Chemistry, 68, 614-617.

Mazhar, H., \& Chandrashekar, A. (1995). Quantification and distribution of kafirins in the kernels of sorghum cultivars varying in endosperm hardness. Journal of Cereal Science, 21, 155-162.

Parejo, I., Jauregui, O., Sanchez-Rabaneda, F., Viladomat, F., Bastida, J., \& Codina, C. (2004). Separation and characterization of phenolic compounds in fennel (Foeniculum vulgare) using liquid chromatography-negative electrospray ionization tandem spectrometry. Journal of Agricultural and Food Chemistry, 52, 3679-3687.

Paulsen, M. R., Watson, S. A., \& Singh, M. (2003). Measurement and maintenance of corn quality. In L. Johnson and P. White (Eds) Corn: Chemistry and Technology (pp 159219). AACC. St. Paul MN.

Del Pozo-Insfran, D. D., Brenes, C. H., Saldivar, S. O. S., \& Talcott, S. T. (2006). Polyphenolic and antioxidant content of white and blue corn (Zea mays L.) products. Food Research International, 39, 696-703.

Qiu, Y., Liu, Q., \& Beta, T. (2010). Antioxidant properties of commercial wild rice and analysis of soluble and insoluble phenolic acids. Food Chemistry, 121, 140-147.

Ralph. J, Hatfield, R. D, Quideau S, Helm R. F, Grabber J. H, \& Jung., H-J. G. (1994). Pathway of $p$-coumaric acid incorporation into maize lignin as revealed by NMR. Journal of the American Chemical Society, 116, 9448-9456.

Rao, R. S. P., \& Muralikrishna, G. (2004). Non-starch polysaccharide-phenolic acid complexes from native and germinated cereals and millet. Food Chemistry, 84, 527531.

Renger, A., \& Steinhart, H. (2000). Ferulic acid dehydrodimers as structural elements in cereal dietary fibre. European Food Research and Technology, 211, 422-428.

Ring, A. S., Waniska, R. D., \& Rooney L. W. (1988). Phenolic compounds in different sorghum tissues during maturation. Biomass, 17, 39-49. 
Reichert, R. D., Tyler, R. T., York, A. E., Schwab, D. J., Tatarynovich, J. E., \& Mwasaru, M. A. (1986). Description of a production model of the Tangential Abrasive Dehulling Device and its application to breeder's samples. Cereal Chemistry, 63, 201-207.

Robutti, J. L. (1995). Maize kernel hardness estimation in breeding by near-infrared transmission analysis. Cereal Chemistry, 72, 632-636.

Rooney, L. W., \& Miller, F. R. (1982). Variations in the structure and kernel characteristics of sorghum. In L.W. Rooney and D.S. Murty, (Eds.), Proceedings in International Symposium on Sorghum Grain Quality. (pp 143-162). ICRISAT: Patancheru, A.P., India.

Sun R., Sun X. F., Wang S.Q., Zhu W., \& Wang X. Y. (2002). Ester and ether linkages between hydroxycinnamic acids and lignins from wheat, rice, rye, and barley straws, maize stems, and fast-growing poplar wood. Industrial Crops and Products, 15, 178188.

Torre. P., Aliakbarian, B., Rivas, B., Dominguez, J. M., \& Converti, A. (2008). Release of ferulic acid from corn cobs by alkaline hydrolysis. Biochemical Engineering Journal, $40,500-506$.

Waldron, K. W., Parr, A. J., Ng, A., \& Ralph, J. (1996). Cell wall esterified phenolic dimmers: Identification and quantification by reverse phases high performance liquid chromatography and diode array detection. Phytochemical Analysis, 7, 305-312.

Waterman, P. G., \& S. Mole. (1994). Analysis of Phenolic Plant Metabolites. Blackwell Scientific Publications, Oxford.

Wehling, R. L., Jackson, D. S., \& Hamaker, B. R. (1996). Prediction of corn dry milling quality by near-infrared spectroscopy. Cereal Chemistry, 73, 543-546. 


\section{Table 1a}

Physical and hardness characteristics of sorghum ${ }^{\mathrm{a}, \mathrm{b}}$

\begin{tabular}{|c|c|c|c|c|c|c|c|}
\hline Cultivar & TW & TKW & $>4.00 \mathrm{~mm}$ & $>3.35<4.00 \mathrm{~mm}$ & $>3.15<3.35 \mathrm{~mm}$ & $>2.36<3.15 \mathrm{~mm}$ & TADD \\
\hline \multicolumn{8}{|c|}{ Hard Cultivars } \\
\hline PAN 8902 & $77.7 \mathrm{aA}(0.3)$ & $25.7 \mathrm{aA}(1.2)$ & $0.6 \mathrm{cdB}(0.05)$ & $62.6 \mathrm{aAB}(0.3)$ & $18.2 \mathrm{bA}(0.1)$ & $13.2 \mathrm{bA}(0.7)$ & $32.7 \mathrm{bcAB}(3.5)$ \\
\hline PAN 8905 & $75.9 \mathrm{bB}(0.0)$ & $26.2 \mathrm{aA}(0.9)$ & $0.6 \mathrm{cdB}(0.30)$ & $62.9 \mathrm{aAB}(0.3)$ & $18.8 \mathrm{bA}(0.4)$ & $11.5 \mathrm{cdB}(0.2)$ & $36.2 \mathrm{abcA}(1.5)$ \\
\hline PAN 8564 & $76.9 \mathrm{aA}(0.5)$ & $25.0 \mathrm{aA}(1.0)$ & $0.3 \mathrm{dC}(0.11)$ & $52.5 \mathrm{cC}(1.4)$ & $17.0 \mathrm{bcB}(0.5)$ & $9.9 \mathrm{efC}(0.1)$ & $37.6 \mathrm{abcA}(2.1)$ \\
\hline PAN 8488 & $77.4 \mathrm{aA}(0.2)$ & $25.5 \mathrm{aA}(0.6)$ & $3.6 \mathrm{aA}(0.25)$ & $65.8 \mathrm{aA}(3.4)$ & $11.8 \mathrm{dC}(0.4)$ & $13.0 \mathrm{bA}(0.2)$ & $26.7 \mathrm{cC}(3.2)$ \\
\hline Mean & $77.0^{\mathrm{a}}(0.7)$ & $25.6^{\mathrm{a}}(0.9)$ & $1.3^{\mathrm{a}}(1.46)$ & $60.9^{\mathrm{a}}(5.6)$ & $16.5^{\mathrm{a}}(3.0)$ & $11.9^{\mathrm{a}}(1.4)$ & $\mathbf{3 3 . 3}^{\mathrm{a}}(4.9)$ \\
\hline \multicolumn{8}{|c|}{ Soft Cultivars } \\
\hline PAN 8901 & $77.7 \mathrm{aA}(0.3)$ & $25.3 \mathrm{aB}(1.9)$ & $0.1 \mathrm{dC}(0.0)$ & $65.8 \mathrm{aA}(0.8)$ & $14.6 \mathrm{cdB}(0.6)$ & $12.6 \mathrm{bcB}(0.1)$ & $49.2 \mathrm{aA}(9.1)$ \\
\hline PAN 8903 & $76.4 \mathrm{aA}(0.6)$ & $26.8 \mathrm{aAB}(0.7)$ & $2.1 \mathrm{bA}(0.4)$ & $55.6 \mathrm{bcC}(0.5)$ & $13.4 \mathrm{dC}(0.1)$ & $10.4 \mathrm{deC}(0.3)$ & $42.3 \mathrm{abcB}(2.0)$ \\
\hline PAN 8906 & $75.6 \mathrm{bB}(0.3)$ & $28.0 \mathrm{aA}(0.8)$ & $1.4 \mathrm{cB}(0.4)$ & 61.9abB(2.7) & $12.5 \mathrm{dD}(0.1)$ & $8.8 \mathrm{fD}(0.3)$ & $38.4 \mathrm{abcB}(1.4)$ \\
\hline PAN 8904 & $75.2 \mathrm{bB}(0.3)$ & $19.8 \mathrm{bC}(1.2)$ & $2.2 \mathrm{bA}(0.1)$ & $19.4 \mathrm{dD}(0.3)$ & $31.2 \mathrm{aA}(2.3)$ & $38.5 \mathrm{aA}(0.6)$ & $45.1 \mathrm{aA}(2.1)$ \\
\hline Mean & $76.2^{\mathrm{a}}(1.0)$ & $25.0^{\mathrm{a}}(3.5)$ & $1.4^{\mathrm{a}}(0.9)$ & $\mathbf{5 0 . 7}^{\mathbf{b}}(19.7)$ & $17.9^{\mathrm{a}}(8.3)$ & $17.6^{\mathrm{a}}(13.0)$ & $\mathbf{4 2 . 6}^{\mathrm{a}}(6.3)$ \\
\hline
\end{tabular}

${ }^{a}$ All cultivars were bred by Pannar Seed South Africa; TW, test weight (kg/hl); TKW; thousand kernel weight (g); kernels passing through > $2.36 \mathrm{~mm}>4.00 \mathrm{~mm}(\mathrm{~g})$; TADD; \% kernel removed by TADD abrasion

${ }^{\mathrm{b}}$ Figures in parentheses are standard deviations. Different lower case, uppercase and superscript letters in the same column denote significant differences ( $\mathrm{p}$ < 0.05) among all cultivars, within the hard and soft and between hard and soft cultivars, respectively. 
Table 1b

Physical and hardness characteristics of maize cultivars ${ }^{\text {a,b }}$

\begin{tabular}{lcccccc}
\hline \multicolumn{1}{c}{ Cultivar } & TW & SB & KS & TKW & TADD & NIT \\
\hline Hard cultivars & & & & & & \\
IMP 52 - 11 & $81.5(1.5)$ & $2.26(1.57)$ & $83.0(1.0)$ & $397(53)$ & $25.2(2.0)$ & $98.8(7.1)$ \\
DKC 77 - 61 B & $79.9(1.5)$ & $1.98(0.04)$ & $74.5(10.5)$ & $438(9)$ & $24.2(0.9)$ & $91.0(6.7)$ \\
AFG 4555 & $82.0(0.2)$ & $2.73(0.34)$ & $77.1(10.1)$ & $444(3)$ & $23.7(3.4)$ & $93.7(6.5)$ \\
LS 8521 B & $79.4(0.3)$ & $2.57(0.89)$ & $78.2(2.3)$ & $404(8)$ & $23.4(2.3)$ & $99.6(5.2)$ \\
Mean & $80.6(1.4)$ & $\mathbf{2 . 3 8}(0.76)$ & $78.2(6.5)$ & $\mathbf{4 2 1}(48)$ & $\mathbf{2 4 . 1}(1.9)$ & $95.8(6.2)$ \\
\hline Soft cultivars & & & & & \\
PAN 6223 B & $78.6(3.3)$ & $4.04(0.41)$ & $83.7(5.6)$ & $373(54)$ & $31.2(3.3)$ & $85.0(11.1)$ \\
PAN 4P - 313 B & $80.0(1.0)$ & $1.70(0.30)$ & $82.7(1.1)$ & $403(37)$ & $29.1(2.0)$ & $86.3(5.5)$ \\
AFG 4473 & $86.1(8.1)$ & $3.55(0.83)$ & $80.3(0.2)$ & $422(3)$ & $29.6(2.0)$ & $95.7(3.4)$ \\
AFG 4517 & $79.9(2.5)$ & $4.11(0.55)$ & $77.0(0.6)$ & $413(23)$ & $31.2(2.4)$ & $84.2(1.2)$ \\
Mean & $81.2(4.7)$ & $\mathbf{3 . 3 5}(1.13)$ & $80.9(3.5)$ & $\mathbf{4 0 3}(33)$ & $\mathbf{3 0 . 3}(2.1)$ & $87.8(6.9)$ \\
\hline
\end{tabular}

${ }^{a}$ Cultivars were bred by South African-based seed companies Agricol, Monsanto, Afgri, Link, Pannar, Pannar, Afgri, Afgri, respectively; TW, test weight $(\mathrm{kg} / \mathrm{hl}) ; \mathrm{SB}$, \% breakage susceptibility by Steiner breakage tester; TKW; thousand kernel weight (g); TADD; \% kernel removed by TADD abrasion; KS; $\%$ kernel size $\geq 8 \mathrm{~mm}$; NIT, Near Infrared Transmittance milling index

${ }^{\mathrm{b}}$ Figures in parentheses are standard deviations. Means were not significantly different $(\mathrm{p}<0.05)$ 
Table 2

Total phenolic content of sorghum and maize bran and flour fractions ( $\mathrm{g} / 100 \mathrm{~g}$ catechin equivalents $)^{\mathrm{a}}$

\begin{tabular}{|c|c|c|c|c|c|}
\hline \multicolumn{3}{|c|}{ Sorghum } & \multicolumn{3}{|c|}{ Maize } \\
\hline Cultivar & Bran & Flour & Cultivar & Bran & Flour \\
\hline \multicolumn{6}{|c|}{ Hard cultivars } \\
\hline PAN 8902 & $0.89 \mathrm{abA}(0.17)$ & $0.34 \mathrm{aAB}(0.09)$ & IMP $52-11$ & $0.76 \mathrm{abA}(0.01)$ & $0.29 \mathrm{aA}(0.04)$ \\
\hline PAN 8905 & $0.96 \mathrm{aA}(0.02)$ & $0.29 \mathrm{aB}(0.06)$ & DKC $77-61$ B & $0.78 \mathrm{aA}(0.08)$ & $0.36 \mathrm{aA}(0.02)$ \\
\hline PAN 8564 & $0.96 \mathrm{aA}(0.03)$ & $0.48 \mathrm{aA}(0.01)$ & AFG 4555 & $0.76 \mathrm{abcA}(0.04)$ & $0.29 \mathrm{aA}(0.09)$ \\
\hline PAN 8488 & $0.71 \mathrm{bB}(0.08)$ & $0.37 \mathrm{aAB}(0.18)$ & LS $8521 \mathrm{~B}$ & $0.71 \mathrm{abcA}(0.03)$ & $0.33 \mathrm{aA}(0.01)$ \\
\hline Mean & $0.88^{\mathrm{a}}(0.13)$ & $0.37^{\mathrm{a}}(0.11)$ & Mean & $0.75^{\mathrm{a}}(0.05)$ & $0.31^{\mathrm{a}}(0.05)$ \\
\hline \multicolumn{6}{|c|}{ Soft cultivars } \\
\hline PAN 8901 & $0.70 \mathrm{bcA}(0.11)$ & $0.36 \mathrm{aB}(0.03)$ & PAN 6223 B & $0.50 \mathrm{efA}(0.00)$ & $0.28 \mathrm{aA}(0.04)$ \\
\hline PAN 8903 & $0.77 \mathrm{bcA}(0.04)$ & $0.27 \mathrm{aB}(0.05)$ & PAN 4P - 313 B & $0.59 \operatorname{def} A(0.06)$ & $0.31 \mathrm{aA}(0.00)$ \\
\hline PAN 8906 & $0.63 \mathrm{cB}(0.04)$ & $0.49 \mathrm{aA}(0.06)$ & AFG 4473 & $0.45 \mathrm{fB}(0.03)$ & $0.39 \mathrm{aA}(0.04)$ \\
\hline PAN 8904 & $0.71 \mathrm{bcA}(0.05)$ & $0.31 \mathrm{aB}(0.03)$ & AFG 4517 & $0.56 \operatorname{def} A(0.02)$ & $0.32 \mathrm{aA}(0.04)$ \\
\hline Mean & $0.70^{\mathrm{b}}(0.07)$ & $0.36^{\mathrm{a}}(0.09)$ & Mean & $0.52^{\mathrm{b}}(0.06)$ & $0.33^{\mathrm{a}}(0.03)$ \\
\hline
\end{tabular}

${ }^{a}$ Figures in parentheses are standard deviations. Different lower case, upper case and superscript letters in the same column denote significant differences ( $\mathrm{p}$ < 0.05) among all cultivars, within the hard and soft and between hard and soft cultivars, respectively. 
Table 3a

Bound phenolic acids of sorghum bran and flour fractions $(\mu \mathrm{g} / \mathrm{g})^{\mathrm{a}, \mathrm{b}}$

\begin{tabular}{|c|c|c|c|c|c|c|c|c|c|}
\hline \multirow[b]{2}{*}{ Cultivar } & \multirow[b]{2}{*}{ Caffeic } & \multicolumn{3}{|c|}{ Bran } & \multirow[b]{2}{*}{$\mathrm{DFA}^{\mathrm{a}}$} & \multirow[b]{2}{*}{ BTPA $^{b}$} & \multicolumn{2}{|c|}{ Flour } & \multirow[b]{2}{*}{ FTPA } \\
\hline & & p-Coumaric & Ferulic & Sinapic & & & $p$-Coumaric & Ferulic & \\
\hline \multicolumn{10}{|c|}{ Hard cultivars } \\
\hline PAN 8902 & 103bBC(16) & $250 \mathrm{cC}(21)$ & $3532 \mathrm{aA}(245)$ & $57.3 \mathrm{bB}(3.6)$ & $436 \mathrm{aA}(47)$ & $4378 \mathrm{aA}(333)$ & $166 \mathrm{aB}(12)$ & $205 \mathrm{aA}(14)$ & $371 \mathrm{aA}(26)$ \\
\hline PAN 8905 & $136 \mathrm{aA}(6)$ & $329 \mathrm{bB}(28)$ & $3507 \mathrm{aA}(166)$ & $51.5 \mathrm{bcB}(4.6)$ & $326 \mathrm{cC}(28)$ & $4350 \mathrm{aA}(233)$ & $198 \mathrm{aA}(8)$ & $185 \mathrm{aB}(13)$ & $383 \mathrm{aA}(21)$ \\
\hline PAN 8564 & $102 \mathrm{bBC}(10)$ & $396 a A(9)$ & $3412 \mathrm{aA}(32)$ & $78.6 \mathrm{aA}(2.8)$ & $406 \mathrm{aA}(18)$ & $4395 \mathrm{aA}(72)$ & $152 \mathrm{aBC}(14)$ & $202 \mathrm{aA}(7)$ & $354 \mathrm{aA}(21)$ \\
\hline PAN 8488 & $83 \mathrm{cC}(6)$ & $223 \mathrm{cC}(12)$ & $2675 \mathrm{bB}(71)$ & $59.3 \mathrm{bB}(0.8)$ & $397 \mathrm{aAB}(18)$ & $3437 \mathrm{bB}(110)$ & $140 \mathrm{aC}(9)$ & $169 \mathrm{bB}(7)$ & $310 \mathrm{aB}(16)$ \\
\hline Mean & $106^{\mathrm{a}}(22)$ & $300^{\mathrm{a}}(79)$ & $3282^{\mathrm{a}}(408)$ & $61.7^{\mathrm{a}}(11.8)$ & $416^{\mathrm{a}}(47)$ & $4140^{\mathrm{a}}(469)$ & $164^{\mathrm{a}}(25)$ & $190^{\mathrm{a}}(17)$ & $354^{\mathrm{a}}(32)$ \\
\hline$\% \mathrm{CV}$ & & & & & & 6.5 & & & 6.9 \\
\hline \multicolumn{10}{|c|}{ Soft cultivars } \\
\hline PAN 8901 & $43 \mathrm{~dB}(1)$ & $103 \mathrm{dC}(9)$ & $1886 \mathrm{~dB}(42)$ & $74.5 \mathrm{aA}(3.1)$ & $341 \mathrm{bcB}(27)$ & $2448 \mathrm{~dB}(82)$ & $70 \mathrm{bB}(4)$ & $89 \mathrm{cA}(9)$ & $160 \mathrm{bA}(13)$ \\
\hline PAN 8903 & $114 \mathrm{bA}(11)$ & $175 \mathrm{cdA}(14)$ & $2401 \mathrm{bcA}(207)$ & $74.5 \mathrm{aA}(3.1)$ & $389 \mathrm{aA}(29)$ & $3153 \mathrm{bcA}(254)$ & $84 \mathrm{bA}(5)$ & $79 \mathrm{cA}(10)$ & $163 \mathrm{bA}(15)$ \\
\hline PAN 8906 & $31 \mathrm{dC}(3)$ & $139 \mathrm{dBC}(25)$ & $2342 \mathrm{cA}(124)$ & 75.0aA(3.8) & $345 \mathrm{bcB}(24)$ & $2939 \mathrm{cA}(180)$ & $26 \mathrm{dC}(1)$ & $81 \mathrm{cA}(7)$ & $107 \mathrm{cB}(7)$ \\
\hline PAN 8904 & $46 \mathrm{~dB}(3)$ & $151 \mathrm{dAB}(6)$ & $1727 \mathrm{dC}(26)$ & $41.4 \mathrm{cB}(3.4)$ & $337 \mathrm{bcB}(16)$ & $2302 \mathrm{~dB}(53)$ & $33 \mathrm{dC}(5)$ & $79 \mathrm{cA}(4)$ & $112 \mathrm{cB}(9)$ \\
\hline Mean & $59^{\mathrm{b}}(38)$ & $142^{\mathrm{b}}(30)$ & $2198^{\mathrm{b}}(148)$ & $66.4^{\mathrm{a}}(17)$ & $353^{\mathrm{a}}(24)$ & $2711^{\mathrm{b}}(402)$ & $53^{\mathrm{b}}(28)$ & $82^{\mathrm{b}}(5)$ & $135^{\mathrm{b}}(30)$ \\
\hline$\% \mathrm{CV}$ & & & & & & 7.3 & & & 8.0 \\
\hline
\end{tabular}

${ }^{a}$ Figures in parentheses are standard deviations. Different lower case, upper case and superscript letters in the same column denote significant differences $(p<0.05)$ among all cultivars, within the hard and soft and between hard and soft cultivars, respectively.

${ }^{\mathrm{b}}$ DFA, diferulic acids; BTPA, total phenolic acid content in bran; FTPA, total phenolic acids in flour; \%CV, average cultivar coefficient of variation 
Table 3b

Bound phenolic acids of maize bran and flour fractions $(\mu \mathrm{g} / \mathrm{g})^{\mathrm{a}, \mathrm{b}}$

\begin{tabular}{|c|c|c|c|c|c|c|c|c|}
\hline \multirow[b]{2}{*}{ Cultivar } & \multirow[b]{2}{*}{$p$-Coumaric } & \multirow[b]{2}{*}{ Ferulic } & \multicolumn{3}{|l|}{ Bran } & \multicolumn{2}{|c|}{ Flour } & \multirow[b]{2}{*}{ FTPA } \\
\hline & & & Sinapic & $\mathrm{DFA}^{\mathrm{a}}$ & BTPA & $p$-Coumaric & Ferulic & \\
\hline \multicolumn{9}{|l|}{ Hard cultivars } \\
\hline IMP $52-11$ & $244 \mathrm{bB}(22)$ & $3471 \mathrm{aA}(142)$ & $89 \mathrm{bB}(2)$ & $320 \mathrm{bcB}(14)$ & $4124 \mathrm{aA}(180)$ & $74.3 \mathrm{aB}(2)$ & $83 \mathrm{bB}(6)$ & $157 \mathrm{bB}(7)$ \\
\hline DKC $77-61$ B & $242 \mathrm{bB}(18)$ & $3273 \mathrm{aA}(137)$ & $123 \mathrm{aA}(7)$ & $350 \mathrm{abB}(17)$ & 3989aA(179) & $83.4 \mathrm{aA}(3)$ & $112 \mathrm{aA}(10)$ & $195 \mathrm{aA}(7)$ \\
\hline AFG 4555 & $488 \mathrm{aA}(21)$ & $3373 \mathrm{aA}(41)$ & $117 \mathrm{aA}(7)$ & $439 \mathrm{aA}(18)$ & $4413 \mathrm{aA}(87)$ & $47.1 \mathrm{cdD}(2)$ & $107 \mathrm{aA}(1)$ & $154 \mathrm{bB}(3)$ \\
\hline LS $8521 \mathrm{~B}$ & $232 \mathrm{bB}(15)$ & 2740bB(186) & $120 \mathrm{aA}(9)$ & $436 \mathrm{aA}(10)$ & $3528 \mathrm{bA}(36)$ & $56.0 \mathrm{bC}(1)$ & $129 \mathrm{aA}(1)$ & $185 \mathrm{aA}(2)$ \\
\hline Mean & $302^{\mathrm{a}}(124)$ & $3214^{\mathrm{a}}(326)$ & $112^{\mathrm{a}}(16)$ & $386^{\mathrm{a}}(18)$ & $4013^{\mathrm{a}}(369)$ & $65.2^{\mathrm{a}}(15)$ & $108^{\mathrm{a}}(18)$ & $173^{\mathrm{a}}(19)$ \\
\hline$\% \mathrm{CV}$ & & & & & 5.2 & & & 2.8 \\
\hline \multicolumn{9}{|l|}{ Soft cultivars } \\
\hline PAN 6223 B & $85 \mathrm{eC}(6)$ & $2044 \mathrm{cdB}(176)$ & $47 \mathrm{dC}(1)$ & $259 \mathrm{cB}(16)$ & $2435 \mathrm{~dB}(199)$ & $21.8 \mathrm{eC}(1)$ & $113 \mathrm{aA}(8)$ & $135 \mathrm{bcA}(7)$ \\
\hline PAN 4P - 313 B & $169 \mathrm{cA}(4)$ & $2742 \mathrm{bA}(158)$ & $68 \mathrm{cA}(0)$ & $267 \mathrm{cB}(24)$ & $3246 \mathrm{cA}(92)$ & $43.8 \mathrm{~dB}(2)$ & $67 \mathrm{cC}(2)$ & $110 \mathrm{cB}(4)$ \\
\hline AFG 4473 & $175 \mathrm{cA}(14)$ & $1973 \mathrm{~dB}(157)$ & $69 \mathrm{cA}(7)$ & $331 \mathrm{bcA}(29)$ & $2548 \mathrm{cdB}(39)$ & $54.0 \mathrm{bcAc}(1)$ & $82 \mathrm{bB}(4)$ & $136 \mathrm{bcA}(4)$ \\
\hline AFG 4517 & $104 \operatorname{deB}(8)$ & $2032 \mathrm{cdB}(100)$ & $61 \mathrm{cdB}(3)$ & $274 \mathrm{cB}(18)$ & $2471 \mathrm{cdB}(92)$ & $52.7 \mathrm{bcA}(5)$ & $63 \mathrm{cC}(1)$ & $115 \mathrm{cB}(6)$ \\
\hline Mean & $133^{\mathrm{b}}(32)$ & $2198^{\mathrm{b}}(356)$ & $61^{\mathrm{b}}(10)$ & $283^{\mathrm{b}}(27)$ & $2675^{\mathrm{b}}(386)$ & $43.1^{\mathrm{b}}(13.9)$ & $81^{\mathrm{a}}(21)$ & $124^{\mathrm{b}}(13)$ \\
\hline$\% \mathrm{CV}$ & & & & & 6.7 & & & 4.2 \\
\hline
\end{tabular}

${ }^{a}$ Figures in parentheses are standard deviations. Different lower case, upper case and superscript letters in the same column denote significant differences ( $p$ < 0.05) among all cultivars, within the hard and soft and between hard and soft cultivars, respectively.

${ }^{\mathrm{b}}$ DFA, diferulic acids; BTPA, total phenolic acid content in bran; FTPA, total phenolic acids in flour; \%CV, average cultivar coefficient of variation 


\section{Table 4a}

Pearson correlation coefficients between sorghum physical and hardness characteristics and phenolic acids of bran and flour fractions ${ }^{\mathrm{a}, \mathrm{b}}$

\begin{tabular}{|c|c|c|c|c|c|c|c|c|c|c|c|c|c|c|c|c|c|}
\hline & TW & TKW & K400 & K335 & K315 & K236 & TADD & BTPC & FTPC & BCA & BPCA & BFA & BSA & FPCA & FFA & DFA & BTPA \\
\hline TKW & 0.260 & & & & & & & & & & & & & & & & \\
\hline K400 & 0.372 & 0.170 & & & & & & & & & & & & & & & \\
\hline K335 & $0.582^{* *}$ & $0.660 * * *$ & $0.575^{* *}$ & & & & & & & & & & & & & & \\
\hline K315 & $-0.449 *$ & $-0.635^{* *}$ & $-0.677 * *$ & $-0.885 * *$ & & & & & & & & & & & & & \\
\hline K236 & $-0.454 *$ & $-0.728 * * *$ & -0.372 & $-0.908 * * *$ & $0.909 * * *$ & & & & & & & & & & & & \\
\hline TADD & -0.230 & $-0.469^{*}$ & -0.252 & -0.370 & 0.376 & 0.368 & & & & & & & & & & & \\
\hline BTPC & 0.109 & 0.063 & $-0.538^{*}$ & 0.042 & 0.175 & -0.164 & -0.191 & & & & & & & & & & \\
\hline FTPC & -0.019 & 0.253 & 0.161 & 0.168 & -0.234 & -0.243 & -0.042 & -0.107 & & & & & & & & & \\
\hline $\mathrm{BCA}$ & 0.416 & 0.185 & -0.314 & 0.236 & -0.046 & -0.224 & $-0.411 *$ & 0.441 & -0.294 & & & & & & & & \\
\hline BPCA & 0.432 & 0.120 & -0.328 & 0.149 & -0.146 & -0.362 & -0.380 & $0.664 * *$ & 0.218 & $0.486^{*}$ & & & & & & & \\
\hline BFA & $0.611^{*}$ & 0.258 & -0.107 & 0.381 & -0.327 & $-0.468 *$ & $-0.447 *$ & $0.553^{*}$ & -0.180 & $0.711^{* *}$ & $0.787 * * *$ & & & & & & \\
\hline BSA & 0.342 & $0.579^{*}$ & 0.292 & $0.508 *$ & $-0.719 * *$ & $-0.723 * *$ & 0.052 & -0.103 & 0.411 & -0.116 & 0.295 & 0.237 & & & & & \\
\hline FPCA & 0.095 & 0.109 & 0.198 & 0.083 & -0.242 & -0.212 & -0.223 & -0.063 & $0.774 * * *$ & -0.314 & 0.404 & -0.113 & 0.392 & & & & \\
\hline FFA & -0.468 & -0.342 & 0.056 & $-0.514 *$ & 0.267 & 0.412 & 0.049 & -0.312 & $0.518 *$ & $-0.619 * *$ & -0.080 & $-0.580^{*}$ & -0.084 & $0.712 * *$ & & & \\
\hline DFA & 0.268 & 0.076 & $0.497 *$ & 0.073 & -0.233 & 0.058 & -0.166 & $-0.564 *$ & -0.154 & 0.229 & -0.256 & 0.040 & 0.049 & -0.112 & -0.046 & & \\
\hline BTPA & $0.597 * *$ & 0.236 & -0.155 & 0.332 & -0.300 & -0.457 & $-0.474 *$ & $0.581 *$ & -0.053 & $0.698^{* *}$ & $0.887 * * *$ & $0.980 * * *$ & 0.269 & 0.061 & $-0.437 *$ & 0.009 & \\
\hline FTPA & 0.078 & 0.014 & -0.021 & 0.119 & -0.095 & -0.127 & -0.389 & 0.142 & 0.398 & 0.044 & 0.388 & 0.134 & 0.012 & $0.492 *$ & 0.272 & -0.162 & 0.227 \\
\hline
\end{tabular}

${ }^{\mathrm{a}} \mathrm{TW}$, Test weight (kg/hl); TKW; Thousand kernel weight (g); TADD; \% kernel abraded by a TADD; BCA; caffeic acid in bran; BPCA, pcoumaric acid in bran; BFA, ferulic acid in bran; BSA; sinapic acid in bran; BTPC, total phenolic content in bran; FTPC; total phenolic content in flour; FPCA, p-coumaric acid in flour, FFA; ferulic acid in flour; DFA, diferulic acids; BTPA, total phenolic acid content in bran; FTPA, total phenolic acids in flour

${ }^{\mathrm{b}}$ Significance at $\mathrm{p}<0.05,0.01$ and 0.001 denoted by $* * *, * * *$, respectively 


\section{Table 4b}

Pearson correlation coefficients between maize physical and hardness characteristics and phenolic acids of bran and flour fractions $\mathrm{s}^{\mathrm{a}, \mathrm{b}}$

\begin{tabular}{|c|c|c|c|c|c|c|c|c|c|c|c|c|c|c|c|}
\hline & TW & SB & TKW & TADD & KS & NIT & BTPC & FTPC & BPCA & BFA & BSA & FPCA & FFA & DFA & BTPA \\
\hline SB & 0.217 & & & & & & & & & & & & & & \\
\hline TKW & 0.010 & 0.020 & & & & & & & & & & & & & \\
\hline TADD & -0.131 & $0.504 *$ & -0.227 & & & & & & & & & & & & \\
\hline KS & 0.152 & -0.045 & $-0.691 * * *$ & 0.010 & & & & & & & & & & & \\
\hline NIT & 0.496 & -0.165 & -0.049 & $-0.648 * * *$ & 0.105 & & & & & & & & & & \\
\hline ВТPC & -0.269 & $-0.554^{*}$ & 0.318 & $-0.717 * * *$ & -0.391 & 0.293 & & & & & & & & & \\
\hline FTPC & $0.503 *$ & 0.230 & 0.226 & -0.036 & 0.095 & 0.068 & -0.320 & & & & & & & & \\
\hline BPCA & $0.579 *$ & -0.131 & 0.148 & -0.135 & 0.008 & 0.475 & -0.167 & $0.587 *$ & & & & & & & \\
\hline BFA & -0.076 & $-0.672 * *$ & 0.190 & $-0.776 * * *$ & -0.077 & 0.438 & $0.881 * * *$ & -0.266 & -0.044 & & & & & & \\
\hline BSA & -0.079 & -0.320 & 0.344 & $-0.585^{*}$ & -0.433 & 0.190 & 0.445 & 0.197 & 0.100 & 0.340 & & & & & \\
\hline FPCA & 0.130 & -0.451 & 0.280 & $-0.542 *$ & -0.305 & 0.425 & $0.625 * *$ & 0.197 & 0.392 & $0.589 * *$ & 0.266 & & & & \\
\hline FFA & -0.207 & -0.035 & 0.132 & $-0.498 *$ & -0.239 & 0.267 & 0.400 & -0.083 & -0.057 & 0.243 & $0.574 *$ & -0.011 & & & \\
\hline DFA & 0.406 & -0.049 & 0.425 & -0.372 & -0.285 & 0.466 & 0.191 & 0.268 & $0.670^{* *}$ & 0.259 & 0.447 & 0.275 & 0.211 & & \\
\hline ВТРА & 0.096 & -0.159 & 0.487 & $-0.508^{*}$ & -0.454 & $0.503 *$ & $0.616^{*}$ & -0.031 & 0.004 & $0.542 *$ & 0.383 & 0.361 & 0.279 & 0.272 & \\
\hline FTPA & -0.085 & -0.306 & 0.277 & $-0.730 * * *$ & -0.377 & 0.474 & 0.703 & 0.055 & 0.196 & $0.556^{*}$ & $0.620^{* *}$ & $0.606^{*}$ & 0.788 & 0.337 & 0.444 \\
\hline
\end{tabular}

${ }^{\mathrm{a}} \mathrm{TW}$, Test weight $(\mathrm{kg} / \mathrm{hl}) ; \mathrm{SB}, \%$ breakage susceptibility by Stein breakage tester; TKW; Thousand kernel weight (g); TADD; \% kernel abraded by TADD; KS; \% kernel size $\geq 8$ mm; NIT, NIT milling index; BTPC, total phenolic content in bran; FTPC; total phenolic content in flour; BPCA, p-coumaric acid in bran; BFA, Ferulic acid in bran; BSA; sinapic acid in bran, FPCA, coumaric acid in flour, FFA; ferulic acid in flour; DFA, diferulic acids; BTPA, total phenolic acid content in bran; FTPA, total phenolic acids in flour

${ }^{\mathrm{b}}$ Significance at $\mathrm{p}<0.05,0.01$ and 0.001 denoted by $* * *, * * *$, respectively 
a

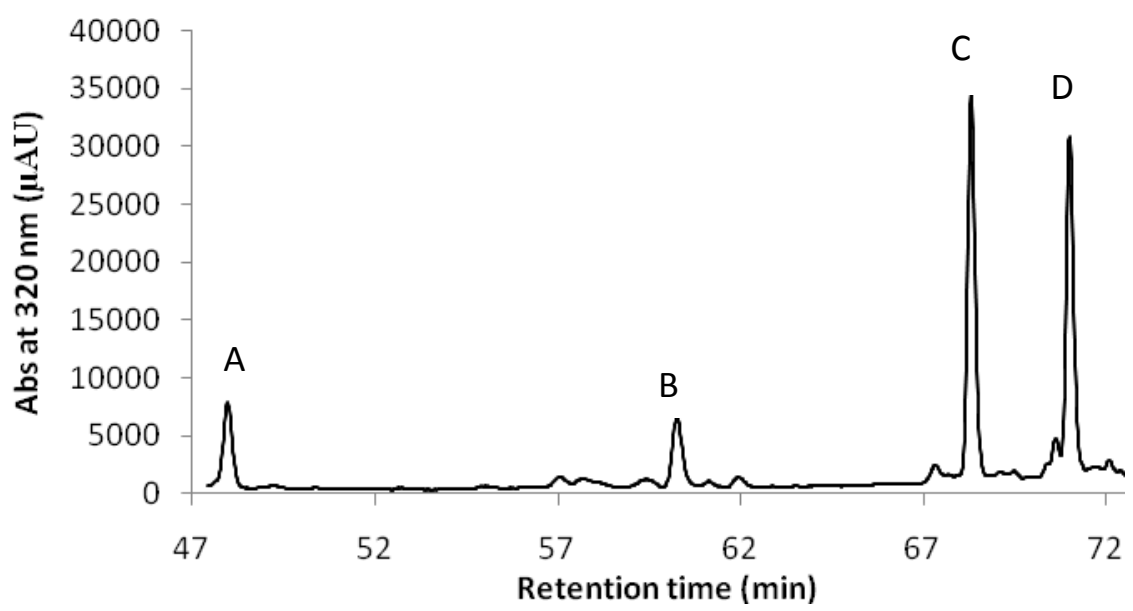

b
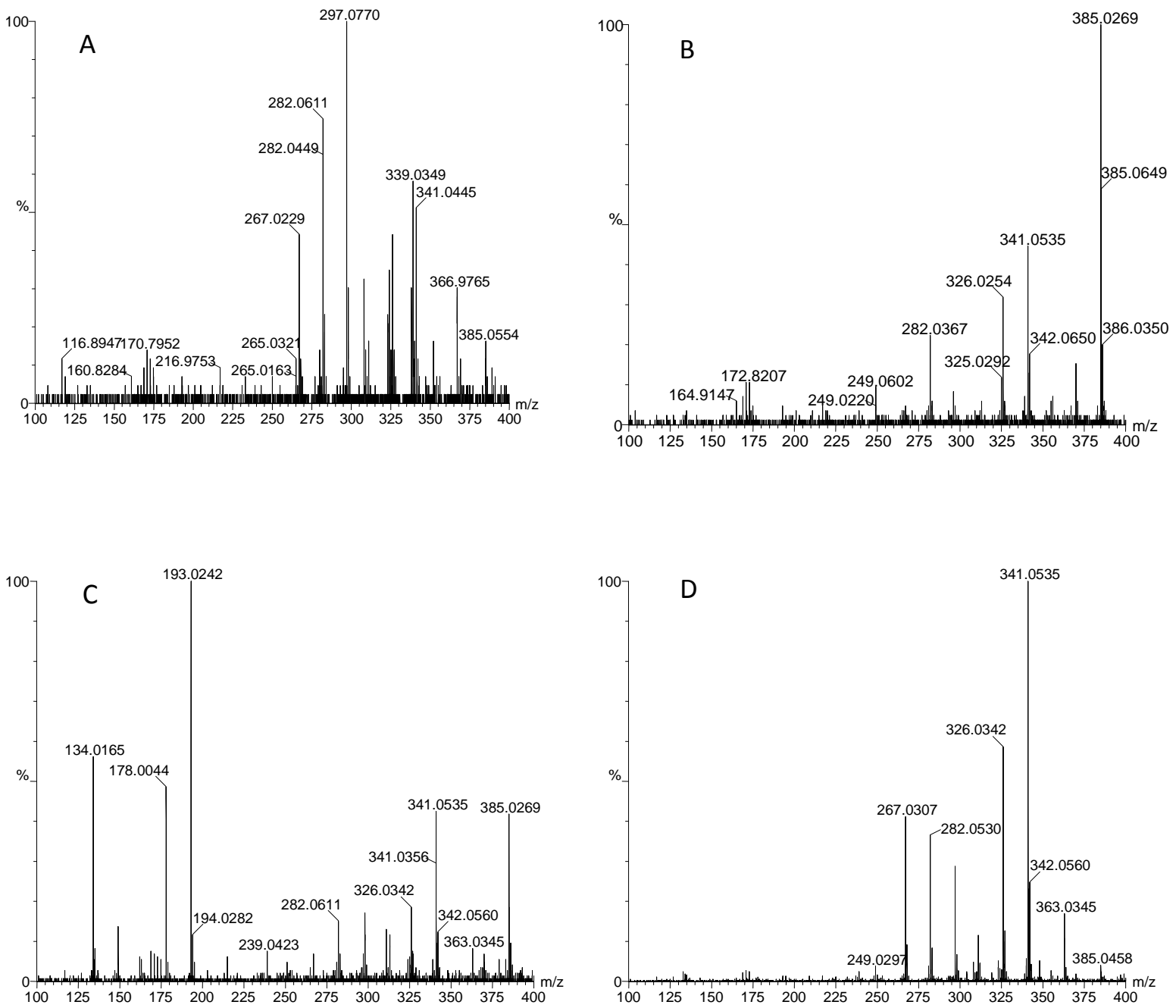

Figure 1. LC chromatogram (a) and MS/MS spectra (b) of diferulic acids 8-8' (A), 5-5' (B), 8-O-4' (C) and 8-5'benzofuran form (D), respectively from the sorghum cultivar PAN 8902. 